\title{
Determinants of Indebtedness: Influence of Behavioral and Demographic Factors
}

\author{
Mahfuzur Rahman ${ }^{1}$, Nurul Azma ${ }^{2}$, Md. Abdul Kaium Masud ${ }^{3,4, *(\mathbb{D})}$ and Yusof Ismail 5 \\ 1 Faculty of Business \& Accountancy, University Malaya, Kuala Lumpur 50603, Malaysia; \\ mahfuzur@um.edu.my \\ 2 Institute for Advanced Studies, University Malaya, Kuala Lumpur 50603, Malaysia; \\ nurulazma87@gmail.com \\ 3 Department of Business Administration, Noakhali Science and Technology University, \\ Noakhali 3814, Bangladesh \\ 4 Department of Sustainability Management, Inha University, Incheon 22212, Korea \\ 5 Kulliyyah of Economics and Management Sciences, IIUM Gombak Campus, Selangor 53100, Malaysia; \\ yusof.edu@gmail.com \\ * Correspondence: masud@nstu.edu.bd
}

Received: 22 December 2019; Accepted: 3 February 2020; Published: 10 February 2020

\begin{abstract}
This study aims to examine the influence of behavioral and demographic factors on indebtedness by constructing a model using specific determinants. The exploratory method is used through the partial least square (SmartPLS) technique, by surveying 320 respondents in Kuala Lumpur, Malaysia. A self-administered questionnaire was administered to respondents, addressing both demographic and behavioral factors. The results confirmed four of the eight hypotheses stated. Among the determinants, risk perception had a highly significant relationship with both materialism and emotion, while indebtedness had a relationship with emotion and materialism. The findings also indicated that significant differences exist between indebtedness and behavioral factors on the basis of gender, marital status, age, income, and dependence on credit cards and loans. The results may assist various economic players to design better models for credit offerings and address the credit problem in the long term.
\end{abstract}

Keywords: indebtedness; behavioral factors; demographic factors; Malaysia

JEL Classification: G32; G110; M300

\section{Introduction}

Credit availability is helpful in ensuring household economic well-being. In Malaysia, particularly after the late-1990s Southeast Asian financial crisis, credit was apparently easily available (Yusoff et al. 2000). Consequently, rising household and individual debts resulted in unprecedented bankruptcy filings, which weakened the intended benefits of this credit availability. Various reports on Malaysian household debt profiles indicate that individuals' spending exceed their income and also that the number of bankruptcy cases in Malaysia is increasing dramatically. The reports also indicated a trend that suggests that the number of bankruptcy cases is more from the economically active age group of 35-44 years, males, and Malays (Loke 2016). Obviously, this presents a disturbing trend for the Malaysian government, which has consequently taken several steps to control the credit problem. However, considering the behavioral factors that quicken the propensity rate toward indebtedness as a given, rather than verifying it, may amount to overstretching assumptions and a policy response flaw (Ottaviani and Vandone 2011). This becomes pertinent when considering that prior studies in behavioral finance found mixed results in establishing a relationship between demographic variables 
and indebtedness, and that behavioral and psychological factors may significantly influence the propensity toward indebtedness.

In addition, this study intends to offer a comprehensive understanding of the causes of individual indebtedness, which may address the credit problem in the long term and help current concerns regarding the rising individual debt in Malaysia. Despite the necessity to understand the behavioral factors so as to avoid unnecessary expenses, few empirical research studies (Flores and Vieira 2014; Ottaviani and Vandone 2011) have highlighted how behavioral factors influence household indebtedness. An attempt to bridge this gap in the existing related literature indicates the relevance of this study.

Moreover, the economic determinants of indebtedness should be able to fully explain the increasing trend of individual indebtedness; however, in the actual scenario, this does not occur. This causes an unexpected increase in family debt, default in debt repayments, and bankruptcy (e.g., Malaysian Department of Insolvency has recorded 253,635 bankruptcy cases from 2007 to 2013). Thus, understanding behavioral factors may improve the current situation by identifying the comprehensive reasons for individual indebtedness, which may, in turn, lead to the development of actions to prevent indebtedness and assist defaulters. Indeed, credit should ideally help people improve their financial condition, such as by assisting them in acquiring assets, covering essential expenses, becoming economically solvent in the long term, and so on. However, in reality, on many occasions credit supply seems to make people more indebted. Many Malaysian people have reported facing financial difficulties and feeling embarrassed by their debt repayments (Endut and Hua 2009; Ghani 2010; Mann et al. 2013). Consequently, the increase in the indebtedness of borrowers has raised public concern about the effects of credit.

Given this scenario, it is important to identify and understand the determinants (behavioral factors) of individual indebtedness. This study considers four determinants highlighted in the literature as the factors influencing indebtedness: financial literacy, risk perception, materialism, and emotion. The major reasons of rising indebtedness are low income, high income, and reluctance to save (Azma et al. 2019). The low-income group justified spending more than they earn because they are unable to cover their basic expenses with their income. They might have to borrow to fulfill their basic expenses. Conversely, it is quite irrational for the high-income group to spend more than they earn, as they can cover their essential expenses with their income. Logically, the high-income group should have some savings instead of having debt. The main reason for the high-income group to be indebted is because of their strong desire to spend. Reluctance to save explains the behavioral factors that mostly influence young people. The foregoing argument motivates this study, that is, it is probable that credit problems are not only produced by economic factors, but also influenced by behavioral factors (Keese 2012; Reed and Cochrane 2012; Selvanathan et al. 2016). Indeed, credit should help people to improve their financial condition, such as to acquire assets, cover essential expenses, and become economically solvent in the long run. Thus, the main objective of the study is to investigate the impact of behavioral and demographic factors that influence the propensity toward indebtedness, and to examine whether there is a difference in the propensity toward indebtedness and behavioral factors among inhabitants in Malaysia across demographic divisions.

The remainder of the paper is structured as follows. Section 2 discusses the theoretical basis of the study. Section 3 describes the methodology and Section 4 presents the results and discussion. Finally, Section 5 presents the conclusion, implications, and limitations.

\section{Theoretical Basis}

Behavioral determinants (e.g., financial literacy, risk perception, materialism, and emotion) may influence the propensity towards indebtedness (Azma et al. 2019; Muñoz-Murillo et al. 2020). The first crucial determinant of this study is financial literacy, which seeks to improve the capacity of persons to understand financial problems. Financial literacy has a greater positive impact on financial outcomes in the long term (Azma et al. 2019). It is an important determinant of whether an individual has sufficient 
savings for future consumption. According to Muñoz-Murillo et al. (2020) and Lusardi et al. (2013), financial literacy is imperative for people who are at an early stage in their career. Parents' financial socialization influences their children's decision-making behavior (Kalwij et al. 2019). For example, Okech et al. (2013) said that children observe how their parents save money, and learn from their actions. Less financial knowledge could affect the financial outcomes in many areas such as retirement planning, borrowing decisions, and stock market participation (Lusardi and Mitchelli 2007; Jalil and Rahman 2010). Ward and Lynch (2019) indicated that financial literacy can help individuals make their financial decisions and income wisely. Flores and Vieira (2014) found that financial literacy has a significant impact on indebtedness. According to Flores and Vieira (2014), Darriet et al. (2020), and Katona (1975) there are three reasons to explain why people spend more than they earn: (i) low-income people cannot cover essential expenses; (ii) high-income people with a strong desire to spend; and (iii) lack of desire to save income. Katona (1975) discussed the origin of the credit problem, and Azma et al. (2019) highlighted psychological and behavioral factors. Following this view, Eberhardt et al. (2019) and Vitt (2004) identified that consumers' financial decisions may reflect their psychological and social values.

The second determinant is risk perception, which indicates how a person views risk during decision-making. Barros and Botelho (2012) suggested that consumers who have a strong expectation for acquisition could underestimate the risk. People with high risk perception tend to have low levels of debt (Nguyen et al. 2019; Caetano et al. 2011). Flores and Vieira (2014) found that risk perception is positively linked with emotion and negatively linked with materialism. Risk perception overcomes uncertainty. Loretts et al. (2019) stated that perception of risk is influenced by the characteristics of farms, whereas market risk is associated with price. Gärling et al. (2009) highlighted that risk perception is an essential component of financial decision-making and other risk-related behaviors.

The third determinant highlighted in the literature is materialism. Materialism is related to the act of consumption (Mishra and Mishra 2016; Richins and Dawson 1992). Chaplin et al. (2019) highlighted the several strategic factors that assist reducing materialism in younger consumers. People with high levels of materialism are characterized as spenders (Azma et al. 2019), while those with low levels are savers because immaterialized people will invest in stocks, bonds, and mutual funds (Chatterjee et al. 2019; Stock and Watson 2003). Santos and Fernandes (2011) observed that people associate excessive materialism with a search for status. Flores and Vieira (2014) stated that when the motivation is anchored in values that are more collectively oriented, materialism is viewed positively. The fourth crucial determinant, emotion, is linked to the individual ability to express emotions when handling financial decisions. Roazzi et al. (2011) contend that emotion constitutes a complex and multifaceted concept and depends on the form of expression. Quelch and Jocz (2007) found that indebtedness affects emotions. According to Huy and Zott (2019), Flores and Vieira (2014) mentioned that emotion influences people's behavior (i.e., consumption, risk-taking, decision-making). In the sociocultural context, each subject gives in to emotions. Considering this context, Roazzi et al. (2011) classify emotions into three categories: background (long-lasting and influential on how primary emotion is expressed, e.g., apathy), primary (people easily express these, e.g., anger and fear), and social (influenced by society and culture, e.g., pride, embarrassment, and jealousy). Flores and Vieira (2014) indicated emotions that consider how indebtedness influences subjective issues (i.e., pride, shame, and nervousness).

The earlier studies (Farrar et al. 2019; Baker et al. 2019; Metawa et al. 2019; Phan et al. 2019) found a relationship between demographic factors and financial behavior (e.g., financial literacy, risk perception, materialism, and emotion). Fletschner and Mesbah (2011) and Farrar et al. (2019) found a significant relationship between gender and financial literacy. Their findings showed that females are less financially informed than males are, but this improves significantly with education, wealth, and encouragement by spouses to acquire and use their finances. Hsu (2016) identified that females are more financially informed when their spouses start to lose cognitive skills. Moreover, risk perception differs based on individual occupations, income, religion, marital status, and level 
of education (Keese 2010). Ponchio (2006) and Lin et al. (2019) focused on the relationship between demographic factors and debt, and identified that men are not more favorable to debt than women are. Younger people tend to perceive their debt burden as significantly lower, whereas those over 45 years are more likely to have a higher debt (Daud et al. 2019; Keese 2010). Older people are less likely to take on debt (Ponchio 2006), and that a lower education level influences the propensity to take on debt (Greig et al. 2019), that is, the lower the education level, the greater the propensity. Flores and Vieira (2014) noted that females are less favorable to debt than males are. Young people, below 30 years of age, tend to take the debt burden lightly as compared to the heads of families aged over 45 years (Keese 2010). This finding shows that the heads of families take the debt burden seriously so that the other family members are not affected by the heads' actions. People aged below 30 years are also found to have higher levels of debt (Flores and Vieira 2014; Sevim et al. 2012). Ahmed et al. (2010) noted that credit card usage could increase the level of personal debt. This is consistent with the findings of Flores and Vieira (2014) indicating that people who use and rely on credit cards are more likely to be in debt.

\section{Methodology}

The study uses the exploratory method, through the partial least square (SmartPLS) technique, and aims to test for specific research hypotheses. A theoretical model is developed to investigate the influence of determinants in debt situations. Additionally, to evaluate demographic and cultural variables, in total, eight hypotheses are considered for testing, as shown in Table 1. These eight hypotheses refer to the described model, which illustrates the relationships among the constructs considered. The eight relationships that refer to demographic and cultural variables are analyzed by hypothesis testing.

This study uses four independent variables (e.g., financial risk tolerance, risk perception, materialism, and emotion) and one dependent variable (indebtedness). For financial literacy, 12 items were adapted from Disney and Gathergood (2011), and for materialism, nine items were used from Ponchio (2006). For risk perception and indebtedness, 13 items were adapted from Caetano et al. (2011) and Flores and Vieira (2014). Emotion was measured by using 10 items adapted from Quelch and Jocz (2007).

Table 1. Hypotheses and research relations with references.

\begin{tabular}{|c|c|c|}
\hline & Hypotheses/Relations & References \\
\hline H1: & Financial literacy positively affects propensity toward indebtedness. & Disney and Gathergood (2011) \\
\hline $\mathrm{H} 2:$ & Risk perception positively affects indebtedness. & Caetano et al. (2011) \\
\hline H3: & Risk perception negatively affects materialism. & Flores and Vieira (2014) \\
\hline $\mathrm{H} 4:$ & Risk perception positively affects emotion. & Flores and Vieira (2014) \\
\hline H5: & Materialism positively affects indebtedness. & Ponchio (2006) \\
\hline H6: & Emotion positively affects indebtedness. & Quelch and Jocz (2007) \\
\hline H7: & $\begin{array}{l}\text { There is a significant difference between demographic variables } \\
\text { with respect to the four determinants. }\end{array}$ & Keese (2010); Flores and Vieira (2014) \\
\hline H8: & $\begin{array}{c}\text { There is a difference between demographic variables with respect to } \\
\text { individual indebtedness. }\end{array}$ & Flores and Vieira (2014) \\
\hline
\end{tabular}

Source: Elaborated by the authors.

The theoretical model provides the idea that the first hypothesis established a relationship between financial literacy and indebtedness. Based on Disney and Gathergood (2011), our efforts decided whether financial literacy positively influences indebtedness. With respect to the construct of risk perception, three hypotheses can be set forth, related to indebtedness, materialism, and emotion. Caetano et al. (2011) indicated that the higher the perceived risk, the lower the level of debt. However, risk perception may also influence indebtedness and emotion. Flores and Vieira (2014) examined that risk perception affects materialism negatively and emotion positively.

Next, the fifth hypothesis of the theoretical model attempts to identify the effect of materialism on indebtedness. Ponchio (2006) found that more materialistic people face or are prone to higher levels of indebtedness. For instance, more materialistic people will probably take up credit for utilization 
purposes. Moreover, the higher the level of materialism, the greater the probability that the individual will be in debt.

The final hypothesis of the theoretical model aims to measure the relationship between emotion and indebtedness. Quelch and Jocz (2007) indicated that consumption affects individuals emotionally. Given this perspective, Flores and Vieira (2014) found that a significant relationship exists between emotion and indebtedness. From the aforementioned hypotheses, a theoretical model is proposed in Figure 1.

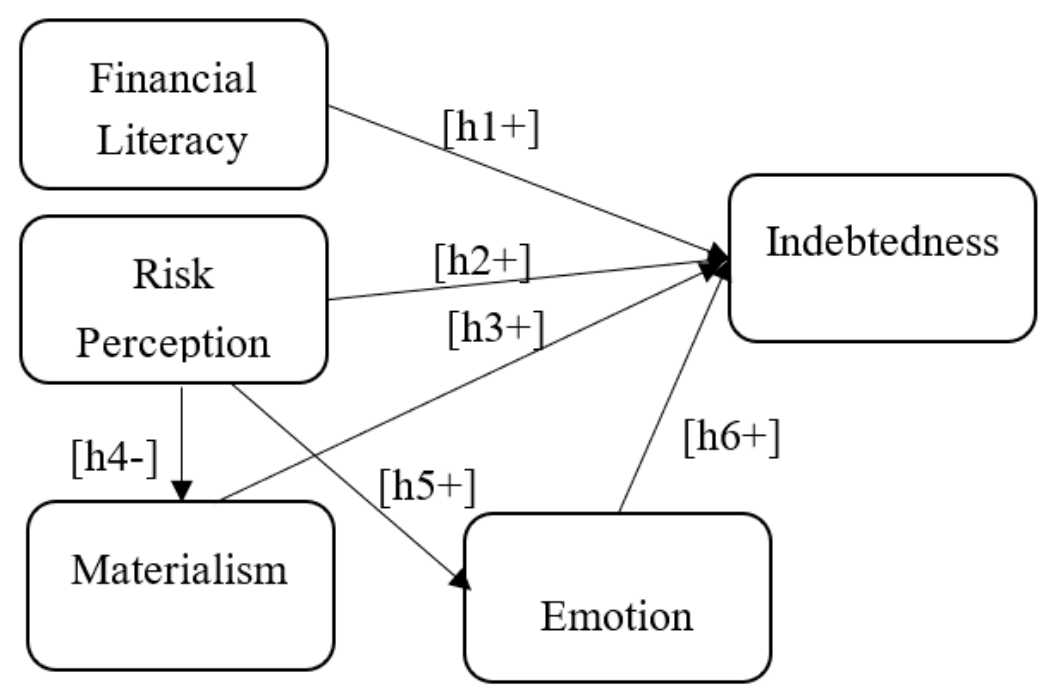

Figure 1. Theoretical model.

The survey for this study was conducted in the city of Kuala Lumpur in Malaysia. The sampling frame consists of working people from both public and private sectors who work within the Kuala Lumpur enclaves. Kuala Lumpur has the highest population density in Malaysia. This population is suitable for analyzing the urban life of these enclaves and their behavior toward financial management. The prospective respondents were chosen using the probability sampling method.

A structured questionnaire, divided into two sections, was used. The first section addressed the respondents' profiles, whereas the second section explored the determinants (behavioral factors) based on the following references: financial literacy, using the scale of Disney and Gathergood (2011); materialism, using the scale of Ponchio (2006); risk perception and indebtedness, based on the scale of Caetano et al. (2011) and Flores and Vieira (2014); and finally, emotion, using the scale of Quelch and Jocz (2007). A five-point Likert scale from 1 (strongly disagree) to 5 (strongly agree) was used for the five factors (financial literacy, risk perception, materialism, emotion, and indebtedness). A total of 400 questionnaires were distributed, of which 350 were returned. The final 320 valid responses presented an actual response rate of $80 \%$.

Using SmartPLS software, the measurement model was assessed, and the hypotheses were tested. PLS is an appropriate tool because it confirms the theories to determine how well a model can estimate a covariance matrix for the sample data. Hair et al. (2013) stated that PLS operates much like a multiple regression analysis and is particularly valuable for exploratory studies.

\section{Results and Discussion}

\subsection{Respondents' Demographic Characteristics}

Data were collected from December 2016 to April 2017, generating a sample of 320 valid responses. According to the respondents' profiles, the statistical analysis shows that the majority of the respondents are males $(58.7 \%)$ compared to females $(41.5 \%)$. The findings also indicate that more than half of the participants are married (53.5\%), while $44.2 \%$ are single, and $2.3 \%$ selected the "others" option. Most 
respondents are aged between 25 and 35 years (55.5\%), followed by those below 24 years (23.2\%) and 36 to 45 years (14.3\%). In terms of educational background, around half of the respondents have a university degree as the highest degree (49.7\%), followed by those with a college degree (28.1\%), and diploma $(22.2 \%)$. The results also reveal that $58.4 \%$ are private-sector employees, followed by those in the public sector $(33.3 \%)$, and finally, the self-employed $(8.3 \%)$.

\subsection{Measurement Model Assessment}

From the methodological point of view, we have considered all the dimensions together for testing the measurement model before the structural model. Having established the different measures, a confirmatory factor analysis (CFA) was conducted. This study used both a measurement model and a structural model. Hence, Table 2 indicates the results of convergent validity of the study. The validity of the constructs and CFA were carried out. The relationships among the constructs were measured using a PLS statistical tool. The findings revealed that factor loading ranged from 0.813 to 0.954 , the value of average variance extracted (AVE) from 0.702 to 0.872 , composite reliability (CR) value between 0.888 and 0.971 , and Cronbach's Alpha value from 0.823 to 0.934 , which indicates convergent validity of this study. In the measurement model estimation, some changes were carried out due to adjustment issues. Table 3 presents the findings of discriminant validity for all the five variables in this study. The discriminant validity of this paper is achieved (see Table 3) because the square root of every latent construct shows the higher correlation. For instance, Hair et al. (2013) indicated that the square root of AVE for each latent variable should be higher than the correlation of any latent variables (Hair et al. 2013). Figure 2 shows the measurement model with regression weights.

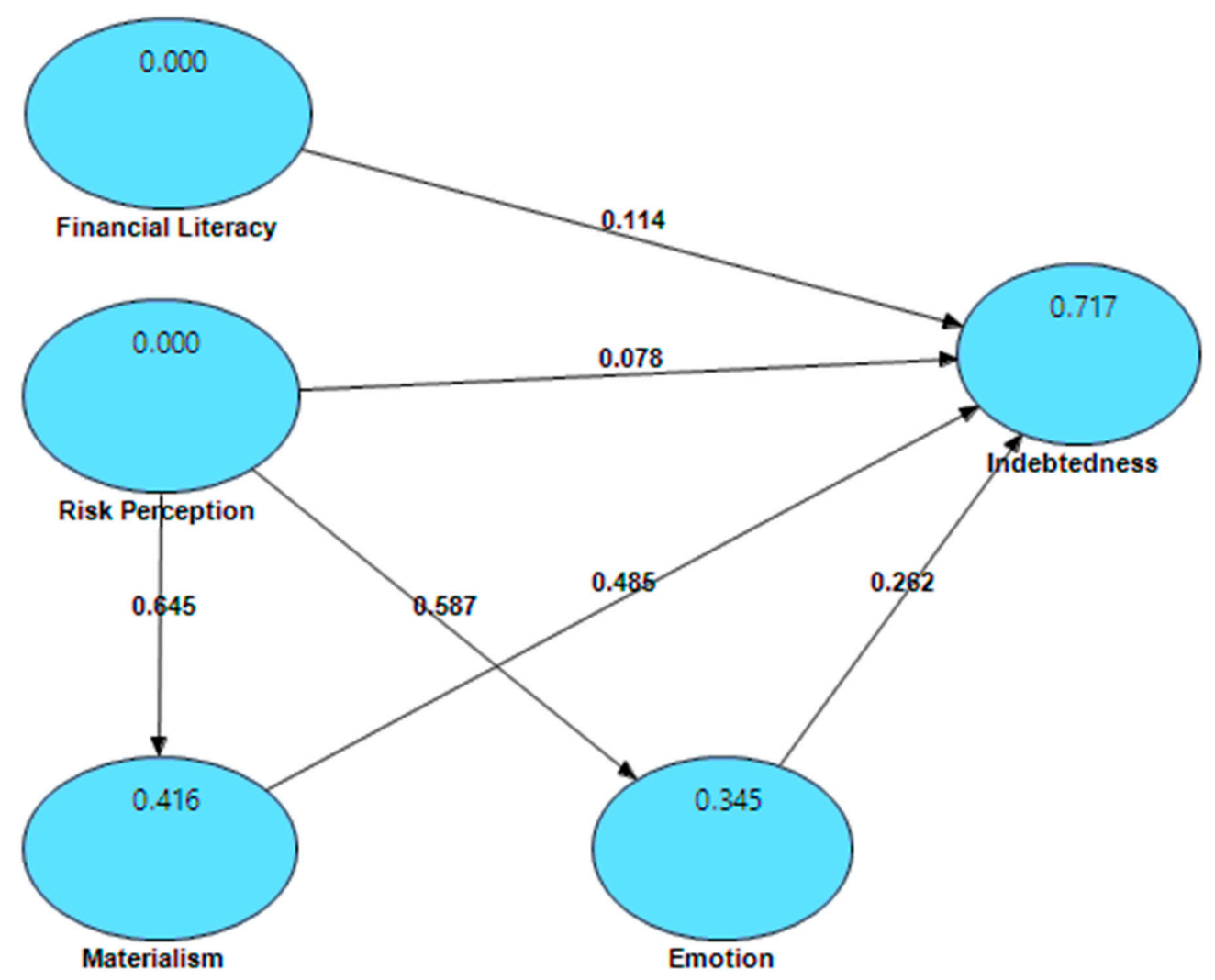

Figure 2. Measurement model. 
Table 2. Convergent validity.

\begin{tabular}{|c|c|c|c|c|c|}
\hline Code & Characteristics & Factor Loadings & AVE & CR & Alpha $(\alpha)$ \\
\hline & Financial Literacy & & 0.806 & 0.954 & 0.934 \\
\hline [FL1] & Saves money every month. & 0.867 & & & \\
\hline [FL2] & Saves to buy more expensive products (e.g., car, house). & 0.822 & & & \\
\hline [FL3] & $\begin{array}{l}\text { Has a financial reserve greater than or equal to three times the monthly income } \\
\text { that can be used in unexpected cases (e.g., unemployment, sickness). }\end{array}$ & 0.846 & & & \\
\hline [FL5] & Analyzes personal finances in depth before making any major purchase. & 0.841 & & & \\
\hline [FL7] & I am satisfied with my own system to control finances. & 0.855 & & & \\
\hline [FL9] & $\begin{array}{l}\text { Uses credit cards because no money is available to cover some expenses. } \\
\text { (if applicable) }\end{array}$ & 0.881 & & & \\
\hline [FL11] & $\begin{array}{l}\text { Pays credit card bill completely to avoid finance charges (interest and fines). } \\
\text { (if applicable) }\end{array}$ & 0.895 & & & \\
\hline \multirow[t]{2}{*}{ [FL12] } & $\begin{array}{l}\text { Checks credit card bills to examine errors and unauthorized charges. } \\
\text { (if applicable) }\end{array}$ & 0.835 & & & \\
\hline & Risk Perception & & 0.872 & 0.971 & 0.824 \\
\hline [RP2] & Accepts being a guarantor for someone. & 0.897 & & & \\
\hline [PR3] & Spends money carelessly, without thinking of the consequences. & 0.920 & & & \\
\hline [RP4] & Invests in businesses that have great chances of not working well. & 0.938 & & & \\
\hline \multirow[t]{2}{*}{ [RP5] } & Lends a great proportion of personal income to a friend or relative. & 0.925 & & & \\
\hline & Materialism & & 0.852 & 0.958 & 0.835 \\
\hline [MT1] & I admire people who possess expensive houses, cars, and clothes. & 0.895 & & & \\
\hline [MT2] & I like to spend money on expensive things. & 0.927 & & & \\
\hline [MT3] & My life would be much better if I had things I actually do not have. & 0.954 & 0.728 & 0.888 & 0.823 \\
\hline [MT4] & Buying gives me pleasure. & 0.916 & & & \\
\hline [MT5] & I would be happier if I could buy more things. & 0.912 & & & \\
\hline [MT6] & I like to possess things to impress other people. & 0.816 & & & \\
\hline [MT8] & It bothers me when I cannot buy everything I want. & 0.887 & & & \\
\hline \multirow[t]{2}{*}{ [MT9] } & Spending much money is among the most important things in my life. & & & & \\
\hline & Emotion & & 0.836 & 0.953 & 0.934 \\
\hline [ET1] & I would feel ashamed if I were indebted. & 0.897 & & & \\
\hline [ET2] & I would feel nervous if I were indebted. & 0.821 & & & \\
\hline [ET4] & I would feel depressed if I were indebted. & 0.853 & & & \\
\hline [ET5] & My dietary habits would be affected if I were indebted. & 0.793 & & & \\
\hline [ET6] & My family relations would suffer if I were indebted. & 0.898 & & & \\
\hline [ET7] & My relations with friends would be harmed if I were indebted. & 0.860 & & & \\
\hline [ET9] & My work performance would be affected if I were indebted. & 0.826 & & & \\
\hline \multirow[t]{2}{*}{ [ET10] } & I would smoke more than usual if I were indebted. & 0.873 & & & \\
\hline & Indebtedness & & 0.703 & 0.904 & 0.862 \\
\hline [ID1] & It is not correct to spend more money than I make. & 0.849 & & & \\
\hline [ID2] & It is better to gather money first and then spend it. & 0.822 & & & \\
\hline [ID3] & I know exactly how much I owe in stores, in credit cards, or to the bank. & 0.892 & & & \\
\hline [ID5] & I would rather buy in installments than to wait to gather money to buy in cash. & 0.862 & & & \\
\hline [ID6] & It is important to know how to control the expenses in my house. & 0.813 & & & \\
\hline [ID7] & I would rather pay in installments even if the total is more expensive. & 0.828 & & & \\
\hline [ID8] & People would be disappointed with me if they knew I had a debt. & 0.884 & & & \\
\hline
\end{tabular}

Table 3. Discriminant validity Fornell-Larcker criterion.

\begin{tabular}{cccccc}
\hline & Emotion & Financial Literacy & Indebtedness & Materialism & Risk Perception \\
\hline Emotion & 0.8977 & & & & \\
Financial & 0.5382 & 0.9143 & & & \\
Literacy & 0.4914 & 0.7414 & 0.8384 & & \\
Indebtedness & 0.4994 & 0.6262 & 0.7844 & 0.9230 & \\
Materialism & 0.5917 & 0.5755 & 0.6068 & 0.9338 \\
Risk Perception & 0.3477 & & & & \\
\hline
\end{tabular}

\subsection{Structural Model}

The findings of the structural model analysis are illustrated in Table 4. In the structural model, the results are examined through beta coefficient $(\beta)$, and $t$-statistics for latent constructs. The findings show that four hypotheses are accepted at significant levels of 0.01 and 0.05 , respectively, while two hypotheses are not accepted. According to Hair et al. (2013), the value of t-statistics equal to or higher than 1.64 are considered significant. The beta coefficient value assesses the strength of the relationship between independent and dependent variables. The beta coefficient value ranges from zero to one, indicating positive or negative significant relationships. The findings illustrate that a higher significant relationship is found between risk perception-materialism $(\beta=0.645)$ followed by risk perception-emotion $(\beta=0.587)$, materialism-indebtedness $(\beta=0.485)$, and emotion-indebtedness $(\beta=0.262)$. Therefore, H3, H4, H5, and $\mathrm{H} 6$ are accepted and $\mathrm{H} 1$ and $\mathrm{H} 2$ are not accepted. Figure 3 
shows the structural model with the hypothesis test. The findings also reveal that the coefficient of determination $\left(R^{2}\right)$ value represents the percentage of variance. Hence, the dependent variables can be explained by independent variables, and range from zero to one. Cohen (1988) assumed that the closer the value to one, the more the independent variable explains the dependent variables. Thus, risk perception explains $41.6 \%$ of materialism and $34.5 \%$ of emotion. In addition, a total variance of indebtedness, $71.7 \%$, is explained by financial literacy, risk perception, materialism, and emotion.

Table 4. Hypothesis testing.

\begin{tabular}{ccccc}
\hline Hypothesis & Hypothesized Relationship & Beta Coefficient $(\beta)$ & $\begin{array}{c}\text { Standard } \\
\text { Error }\end{array}$ & $\boldsymbol{t}$-Statistics \\
\hline H1 & $\begin{array}{c}\text { Financial Literacy } \rightarrow \\
\text { Indebtedness }\end{array}$ & 0.114 & 0.115 & 0.988 \\
H2 & Risk Perception $\rightarrow$ Indebtedness & 0.078 & 0.098 & 0.786 \\
H3 & Risk Perception $\rightarrow$ Materialism & 0.645 & 0.071 & $9.070^{* *}$ \\
H4 & Materialism $\rightarrow$ Indebtedness & 0.485 & 0.125 & $3.864^{* *}$ \\
H5 & Risk Perception $\rightarrow$ Emotion & 0.587 & 0.083 & $7.061^{* *}$ \\
H6 & Emotion $\rightarrow$ Indebtedness & 0.262 & 0.095 & $2.764^{* *}$ \\
\hline
\end{tabular}

Note: ${ }^{* *} p<0.01, * p<0.05$

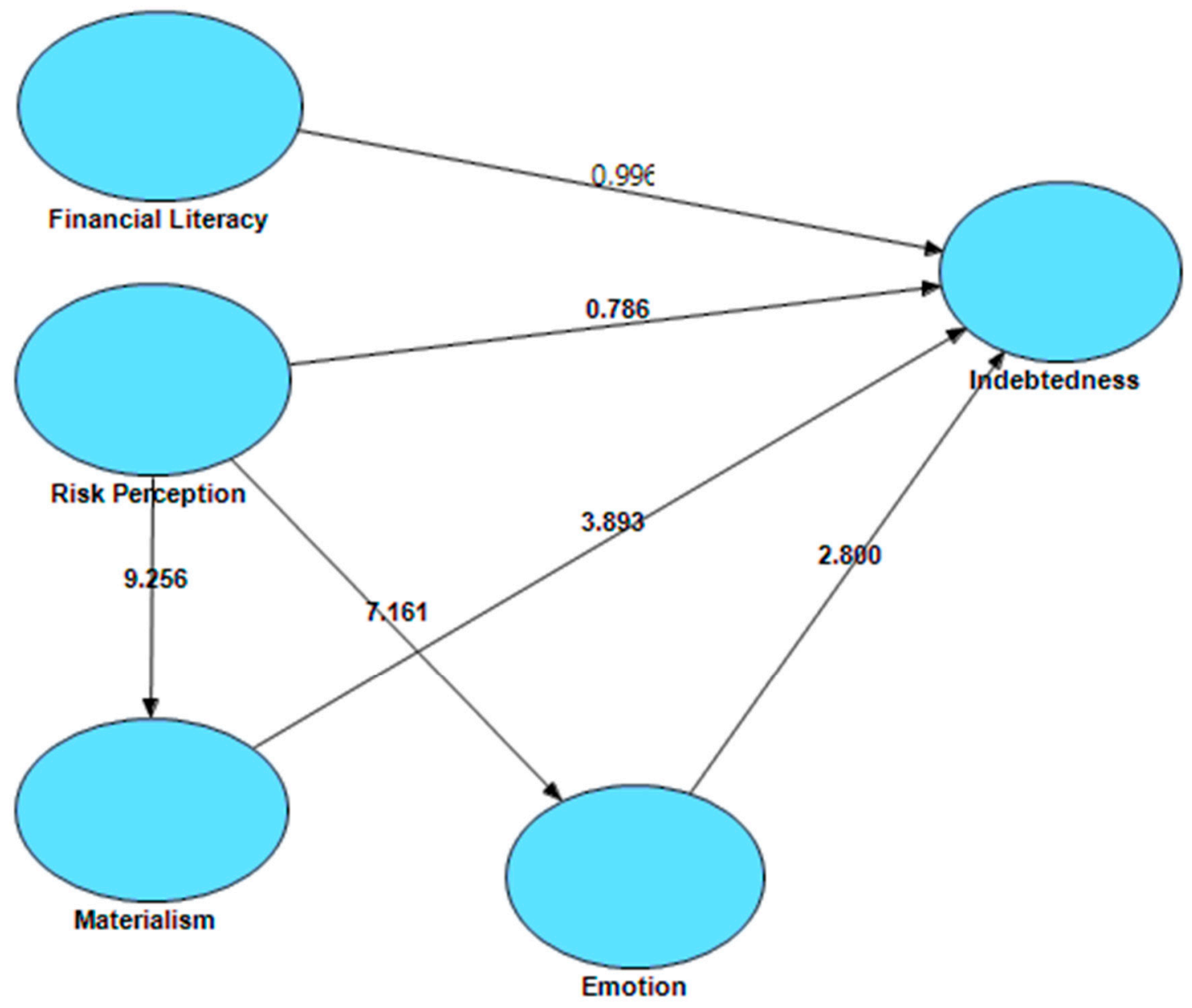

Figure 3. Structural model. Note: $t$-value $\geq 1.64$ significant at $p<0.05, t$-value $\geq 2.32$ significant at $p<0.01$. 


\subsection{Assessment of Demographic Profile and Constructs}

In this study, $t$-tests (for gender, marital status, credit card, and loan) and one-way ANOVA (for age and income) were used to analyze the difference between males and females, single and married people, owning credit card and loan or not; as well as age and income groups in terms of indebtedness, emotion, materialism, risk perception, and financial literacy. Table 5 reposts the $t$-test results that show the difference between males and females in terms of indebtedness, emotion, materialism, risk perception, and financial literacy. The results show that $t$-values for indebtedness and risk perception are statistically significant at $p<0.05$, while materialism is highly statistically significant at $p<0.01$. This finding indicates that there are differences between the means for males and females for all variables. Males scored higher means than females did in indebtedness, materialism, risk perception, and financial literacy, while females scored significantly higher than males in emotion. This indicates that there is no significant difference between males and females in terms of emotion and financial literacy.

Table 5. Relations between demographic profile and constructs.

\begin{tabular}{|c|c|c|c|c|c|}
\hline \multicolumn{6}{|c|}{ Relations between FL, RP, ET, MT, ID, and Gender } \\
\hline Characteristic & ID & ET & MT & $\mathbf{R P}$ & FL \\
\hline \multicolumn{6}{|l|}{ Gender: } \\
\hline Male & 3.02 & 3.28 & 3.07 & 2.25 & 3.72 \\
\hline Female & 2.74 & 3.40 & 2.61 & 2.03 & 3.70 \\
\hline$t$ & $1.96 *$ & -0.86 & $3.43 * *$ & $1.98 *$ & 0.15 \\
\hline \multicolumn{6}{|c|}{ Relations between FL, RP, ET, MT, ID, and Marital Status } \\
\hline Single & 2.83 & 3.48 & 2.83 & 2.12 & 3.73 \\
\hline Married & 2.81 & 3.30 & 2.68 & 2.07 & 3.69 \\
\hline$t$ & 1.78 & 1.47 & 1.26 & 0.40 & 0.39 \\
\hline \multicolumn{6}{|c|}{ Relations between FL, RP, ET, MT, ID, and Credit Card } \\
\hline Yes & 2.85 & 3.24 & 2.75 & 2.03 & 3.94 \\
\hline No & 2.80 & 3.45 & 2.73 & 2.13 & 3.55 \\
\hline$t$ & 0.37 & $-1.75 *$ & 0.17 & -0.80 & $3.78^{* * *}$ \\
\hline \multicolumn{6}{|c|}{ Relations between FL, RP, ET, MT, ID, and Loan } \\
\hline Yes & 2.86 & 3.28 & 2.77 & 2.09 & 3.74 \\
\hline No & 2.70 & 3.58 & 2.66 & 2.08 & 3.63 \\
\hline$t$ & 1.19 & $-2.36^{* *}$ & 0.73 & 0.45 & 0.99 \\
\hline \multicolumn{6}{|c|}{ Relations between FL, RP, ET, MT, ID, and Age } \\
\hline $21-30$ & 2.84 & 3.38 & 2.81 & 2.17 & 3.59 \\
\hline $31-40$ & 2.80 & 3.31 & 2.72 & 2.08 & 3.86 \\
\hline $41-50$ & 2.79 & 3.46 & 2.38 & 1.67 & 3.75 \\
\hline 51 and above & 2.63 & 3.44 & 2.24 & 1.52 & 3.89 \\
\hline$F$ & 0.16 & 0.17 & 1.81 & $2.25 *$ & $2.20 *$ \\
\hline
\end{tabular}

Note: Independent variables: Financial literacy (FL), Risk perception (RP), Materialism (MT), Emotion (ET). Dependent variable: Indebtedness (ID). ${ }^{* *}$ Significant at $p<0.01,{ }^{* *}$ Significant at $p<0.05,{ }^{*}$ Significant at $p<0.10$.

The findings also indicate that there are differences between the means for single and married people for all constructs. Single people scored higher means than married people did in all five constructs. The t-values of all constructs were not significantly different. This implies that there is no significant difference between single and married people in terms of indebtedness, emotion, materialism, risk perception, and financial literacy. In addition, the statistical result indicates that there is no significant difference between "Yes" and "No" in terms of indebtedness, materialism, and risk perception, while financial literacy shows a highly significant difference between "Yes" and "No." Moreover, the results also reveal that there are differences between the means of having a loan or not having a loan for all variables, as the $\mathrm{t}$-value for emotion was significant at $p<0.05$. Table 5 also reports that there is a significant difference between respondents from four age groups and two constructs 
(risk perception, financial literacy), whereas the rest (indebtedness, emotion, materialism) were found insignificant. However, the age group from 21 to 30 years scored higher means in indebtedness, materialism, and risk perception while the age groups of 41 to 50 years and above 51 years scored higher means in emotional and financial literacy, respectively.

Based on the findings of hypothesis testing, materialism and emotion have a significant relationship with a propensity toward indebtedness. These findings are associated with the study of Flores and Vieira (2014). In the context of propensity toward indebtedness in Malaysia, the results found that risk perception and financial literacy are not statistically significant with indebtedness. This result is contradictory with the earlier study of Flores and Vieira (2014) because they found that financial literacy and risk perception have a significant relationship with indebtedness in the context of Brazil. With respect to the sign of the coefficient of financial literacy, the hypothesis related to this issue is not confirmed. Interestingly, this study found that financial literacy was neither practically nor statistically significant to indebtedness. In case of Malaysia, this study suggests that financially literate people are more prone to indebtedness possibly because they have the confidence in managing their debt. They probably know better the function of loans or credit cards, the implications of interest rates, duration of repayment, etc. Conversely, financially illiterate people are less confident in taking on debts possibly because they have insufficient knowledge about the functions and implications of debt.

Flores and Vieira (2014) assume that people with high risk perception tend to have low levels of debt. This finding is consistent with the finding of the present study. Moreover, the statistical analysis reveals that risk perception has a higher significant and positive relationship with materialism and emotion. This study is a new finding in the context of Malaysia and is not associated with Flores and Vieira (2014), who examined the context of Brazil and found that risk perception affects materialism negatively and emotion positively. They also noted that high consumption levels do not always provide benefits; on the contrary, such consumption levels may adversely affect individual welfare. The positive relationship between materialism and indebtedness is noteworthy; indeed, there is a positive relationship, indicating that people with high levels of materialism tend to have a high propensity toward indebtedness. People who value possession of goods highly tend toward a higher propensity of being in debt because they are prone to spending without proper planning.

Regarding the relations of demographic variables to indebtedness, the results of the current study show that males are more likely to be in debt than females are, in accordance with the results of Flores and Vieira (2014). However, this study found no significant difference between single and married people with respect to indebtedness. However, Gathergood (2012) found that single people tend to have a higher propensity toward indebtedness compared to married people. Therefore, further investigation is needed to confirm the result. People who use credit cards have higher debt levels, although the difference is not significant, supporting Ahmed et al. (2010). With respect to age, young people (under 30 years) are more likely to be in debt, according to the results of Disney and Gathergood (2011) and Sevim et al. (2012). However, their differences are not statistically significant. Further, respondents who take loans are more indebted compared to those who do not take loans. This result is similar with that of Flores and Vieira (2014).

\section{Conclusions, Implications, and Limitations}

Propensity toward indebtedness is one of the main serious issues in Malaysia. Although many people have not realized this situation, it presents a great concern to the government, decision makers, and researchers. Therefore, initiatives should be undertaken seriously for overcoming this challenge. The present study tries empirically to address the gap in the literature of the behavioral factors that predict the propensity toward indebtedness. The findings suggest that behavioral factors are among the reasons that cause indebtedness. Self-control is important to avoid being indebted, especially considering that materialism is the only statistically significant factor explaining the propensity toward indebtedness in this study's hypothesized model. This contribution could be a useful source of information for the higher authority to guide people to improve their financial planning through 
programs and mass media. The empirical evidence exists to demonstrate that there are many possible causes of the increasing level of debt worldwide. The results from this study can contribute to the existing line of research in behavioral finance and personal financial management. The study précises diverse behavioral and demographic factors that may influence the propensity toward indebtedness in Malaysia. In terms of practical contributions, this study helps broaden the understanding of behavioral factors, which may lead to the development of actions to prevent indebtedness and assist defaulters. The researcher also hopes that financial institutions could benefit from the results of this study by building stronger models of credit offerings.

In addition, this study suggests that financial institutions may have to improve their model in addressing credit problems in the long term. As materialism is a significant factor explaining the propensity toward indebtedness, the higher authority should consider this behavioral factor and take the necessary steps to guide people to have better financial planning and disseminate it widely through programs and mass media. Financial institutions should measure people's level of materialism before approving loan applications, as it is directly linked to indebtedness. For example, the loan application of a highly materialistic person should be considered carefully. In their efforts to reduce the indebtedness among Malaysians, financial institutions should urgently impose reasonable down payment for house and car loans, and should check thoroughly people's sources of funds to pay the installments.

Besides, in order to reduce the occurrence of moral hazards after taking a business loan, financial institutions should closely monitor how the recipients are spending their funds. A post-disbursement monitoring system would include close supervision of the status or progress of the business undertaken and some technical assistance in achieving a viable business project. This includes offering advice during the initial stage, ensuring consistent progress evaluation, marketing, and ensuring business continuity. Even though borrowing enables individuals to improve their lifestyle and consumption, some individuals are at risk of indebtedness that is unsustainable with their earnings and may reach over-indebtedness. Over-indebted people are prone to suffer from poor psychological well-being, health problems, and weak social networks. Thus, governments should focus on this aspect and conduct programs that could enhance people's understanding about both the benefits and harmful effects of debts.

This study has some limitations. For example, the scope of this study is confined to only the Klang Valley area. Working individuals may differ from those in the other states in terms of experiences and characteristics. These elements may affect individual propensities toward indebtedness. Thus, generalizing this aspect to the Malaysian population is imperative. Future research may carry out comparative studies between people in private and public sectors, or those who work in different states in Malaysia. This strategy could help explore the underlying reasons, and the truth about people being indebted, based on the experiences gained by financial advisors as well as the bankrupted people.

Author Contributions: M.R. carried out the literature review, statistical analysis, and drafted the manuscript. N.A. and Y.I. helped with the data collections, data analysis, and discussion. M.A.K.M. participated in the discussion, and communicated with the editor. All authors read and approved the final manuscript.

Acknowledgments: We would like to acknowledge the financial support provided by Fundamental Research Grant Scheme (FRGS) (Project No. FP058-2017A).

Conflicts of Interest: The authors declare that they have no conflicting interests.

\section{References}

Ahmed, Zafar U., Ishak Ismail, M. Sadiq Sohail, Ibrahim Tabsh, and Hasbalaila Alias. 2010. Malaysian consumers' credit card usage behavior. Asia Pacific Journal of Marketing and Logistics 22: 528-44. [CrossRef]

Azma, Nurul, Mahfuzur Rahman, Adewale Abideen Adeyemi, and Muhammad Khalilur Rahman. 2019. Propensity toward indebtedness: Evidence from Malaysia. Review of Behavioral Finance 11: 188-200. [CrossRef] 
Baker, H. Kent, Satish Kumar, Nisha Goyal, and Vidhu Gaur. 2019. How financial literacy and demographic variables relate to behavioral biases. Managerial Finance 45: 124-46. [CrossRef]

Barros, Lucia, and Delane Botelho. 2012. Hope, perceived financial risk and propensity for indebtedness. BAR-Brazilian Administration Review 9: 454-74. [CrossRef]

Caetano, Gregorio, Miguel Palacios, and Harry Anthony Patrinos. 2011. Measuring Aversion to Debt: Experiments among Student Loan Candidates. Social Science Research Network. Available online: http://papers.ssrn.com/ sol3/papers.cfm?abstract_id=1895966 (accessed on 26 November 2019).

Chaplin, Lan Nguyen, Deborah Roedder John, Aric Rindfleisch, and Jeffrey J. Froh. 2019. The impact of gratitude on adolescent materialism and generosity. The Journal of Positive Psychology 14: 502-11. [CrossRef]

Chatterjee, Devlina, Mahendra Kumar, and Kapil K. Dayma. 2019. Income security, social comparisons and materialism. International Journal of Bank Marketing 37: 1041-61. [CrossRef]

Cohen, Jacob. 1988. Statistical Power Analysis for the Behavioral Sciences, 2nd ed. Hillsdale: Lawrence Erlbaum.

Darriet, Elisa, Marianne Guille, Jean-Christophe Vergnaud, and Mariko Shimizu. 2020. Money illusion, financial literacy and numeracy: Experimental evidence. Journal of Economic Psychology 76: 102211. [CrossRef]

Daud, Siti Nurazira Mohd, Ainulashikin Marzuki, Nursilah Ahmad, and Zurina Kefeli. 2019. Financial Vulnerability and Its Determinants: Survey Evidence from Malaysian Households. Emerging Markets Finance and Trade 55: 1991-2003. [CrossRef]

Disney, Richard, and John Gathergood. 2011. Financial Literacy and Indebtedness: New Evidence for UK Consumers. EconPapers. Available online: http://econpapers.repec.org/paper/notnotcfc/11_2f05 (accessed on 26 November 2019).

Eberhardt, Wiebke, Wändi Bruine de Bruin, and JoNell Strough. 2019. Age differences in financial decision making: The benefits of more experience and less negative emotions. Journal of Behavioral Decision Making 32: 79-93. [CrossRef]

Endut, Norhana, and Toh Geok Hua. 2009. Household Debt in Malaysia. BIS Papers No 46. Basel: Bank for International Settlements Communications, pp. 107-16.

Farrar, Sue, Jonathan Moizer, Jonathan Lean, and Mark Hyde. 2019. Gender, financial literacy, and preretirement planning in the UK. Journal of Women and Aging 31: 319-39. [CrossRef]

Fletschner, Diana, and Dina Mesbah. 2011. Gender Disparity in Access to Information: Do Spouses Share What They Know? World Development 39: 1422-33. [CrossRef]

Flores, Silvia Amélia Mendonça, and Kelmara Mendes Vieira. 2014. Propensity toward indebtedness: An analysis using behavioral factors. Journal of Behavioral and Experimental Finance 3: 1-10. [CrossRef]

Gärling, Tommy, Erich Kirchler, Alan Lewis, and Fred Van Raaij. 2009. Psychology, financial decision making, and financial crises. Psychological Science in the Public Interest 10: 1-47. [CrossRef] [PubMed]

Gathergood, John. 2012. Self-control, financial literacy and consumer over-indebtedness. Journal of Economic Psychology 33: 590-602. [CrossRef]

Ghani, Nazreen Abdul. 2010. Household Indebtedness and its Implications for Financial Stability in Malaysia. Household Indebtedness and Its Implications for Financial Stability 67. Available online: https://core.ac.uk/ download/pdf/6281321.pdf\#page=81 (accessed on 29 November 2019).

Greig, Bruce, Peter Nuthall, and Kevin Old. 2019. Farmers' characteristics' and the propensity to reduce debt. Agricultural Finance Review 79: 614-32. [CrossRef]

Hair, Joseph F., Jr., G. Tomas M. Hult, Christian Ringle, and Marko Sarstedt. 2013. A primer on partial Least Squares Structural Equation Modeling (PLS-SEM). Thousand Oaks: Sage.

Hsu, Joanne W. 2016. Aging and strategic learning: The impact of spousal incentives on financial literacy. Journal of Human Resources 51: 1036-67. [CrossRef]

Huy, Quy, and Christoph Zott. 2019. Exploring the affective underpinnings of dynamic managerial capabilities: How managers' emotion regulation behaviors mobilize resources for their firms. Strategic Management Journal 40: 28-54. [CrossRef]

Jalil, Abdul, and Muhammad Khalilur Rahman. 2010. Financial transactions in Islamic Banking are viable alternatives to the conventional banking transactions. International Journal of Business and Social Science 1: 219-33.

Kalwij, Adriaan, Rob Alessie, Milena Dinkova, Gea Schonewille, Anna Van der Schors, and Minou Van der Werf. 2019. The effects of financial education on financial literacy and savings behavior: Evidence from a controlled field experiment in Dutch primary schools. Journal of Consumer Affairs 53: 699-730. [CrossRef] 
Katona, George. 1975. Psychological Economics. New York: Elsevier.

Keese, Matthias. 2010. Who Feels Constrained by High Debt Burdens? Subjective vs. Objective Measures of Household Indebtedness. Available online: https://papers.ssrn.com/sol3/papers.cfm?abstract_id=1592417 (accessed on 10 February 2020).

Keese, Matthias. 2012. Who feels constrained by high debt burdens? Subjective vs. objective measures of household debt. Journal of Economic Psychology 33: 125-41. [CrossRef]

Lin, Liqiong, Mohamad Dian Revindo, Christopher Gan, and David A. Cohen. 2019. Determinants of credit card spending and debt of Chinese consumers. International Journal of Bank Marketing 37: 545-64. [CrossRef]

Loke, Yiing Jia. 2016. Living beyond one's means: Evidence from Malaysia. International Journal of Social Economics 43: 2-18. [CrossRef]

Loretts, Ekaterina, Svetlana Golovina, and Lidiya Smirnova. 2019. Functioning field of farm enterprises in Russia: Uncertainty and risks. In International Scientific and Practical Conference "Digital Agriculture-Development Strategy". Amsterdam: Atlantis Press.

Lusardi, Annamaria, and Olivia S. Mitchelli. 2007. Financial literacy and retirement preparedness: Evidence and implications for financial education. Business Economics 42: 35-44. [CrossRef]

Lusardi, Annamaria, Pierre-Carl Michaud, and Olivia S. Mitchell. 2013. Optimal Financial Knowledge and Wealth Inequality. NBER Working Paper No. 18669. Cambridge: NBER.

Mann, David, Chidambarathanu Narayanan, John Caparusso, and Prabhat Chandra. 2013. Asia Leverage Uncovered. London: Standard Chartered.

Metawa, Noura, M. Kabir Hassan, Saad Metawa, and M. Faisal Safa. 2019. Impact of behavioral factors on investors' financial decisions: Case of the Egyptian stock market. International Journal of Islamic and Middle Eastern Finance and Management 12: 30-55. [CrossRef]

Mishra, Manit, and Sasmita Mishra. 2016. Financial risk tolerance among Indian investors: A multiple discriminant modeling of determinants. Strategic Change 25: 485-500. [CrossRef]

Muñoz-Murillo, Melisa, Pilar B. Álvarez-Franco, and Diego A. Restrepo-Tobón. 2020. The role of cognitive abilities on financial literacy: New experimental evidence. Journal of Behavioral and Experimental Economics 84: 101-482. [CrossRef]

Nguyen, Linh, Gerry Gallery, and Cameron Newton. 2019. The joint influence of financial risk perception and risk tolerance on individual investment decision-making. Accounting \& Finance 59: 747-71.

Okech, David, Yoko Mimura, Teresa Mauldin, and Junghyun Kim. 2013. The Influence of Financial Factors on Motivation to Save among Poor Individuals. Journal of Policy Practice 12: 107-24. [CrossRef]

Ottaviani, Cristina, and Daniela Vandone. 2011. Impulsivity and household indebtedness: Evidence from real life. Journal of Economic Psychology 32: 754-61. [CrossRef]

Phan, Thuy Chung, Marc Oliver Rieger, and Mei Wang. 2019. Segmentation of financial clients by attitudes and behavior. International Journal of Bank Marketing 37: 44-68. [CrossRef]

Ponchio, Mateus Canniatti. 2006. The Influence of Materialism on Consumption Indebtedness in the Context of Low Income Consumers from the City of Sao Paulo. Ph.D. thesis, Escola de Administração de Empresas de São Paulo, Bela Vista, Brazil; p. 175.

Quelch, John A., and Katherine E. Jocz. 2007. Greater Good: How Good Marketing Makes for a Better World. Boston: Harvard Business Press.

Reed, Matthew, and Debbie Cochrane. 2012. Student Debt and the Class of 2011. The Project on Student Debt. Oakland: The Institute of College Access and Success.

Richins, Marsha L., and Scott Dawson. 1992. Consumer values orientation for materialism and its measurement: Scale development and validation. The Journal of Consumer Research 19: 303-16. [CrossRef]

Roazzi, Antonio, Maria da Graça Bompastor Borges Dias, Janaína Oliveira da Silva, Luciana Barboza dos Santos, and Maíra Monteiro Roazzi. 2011. Que é emoção? Em busca da organização estrutural do conceito de emoção em crianças. Psicologia: Reflexão e Crítica 24: 51-61. [CrossRef]

Santos, Cristiane Pizzutti dos, and Daniel Von Der Heyde Fernandes. 2011. A socialização de consumo e a formação do materialismo entre os adolescents. RAM. Revista de Administração Mackenzie 12: 169-203. [CrossRef]

Selvanathan, Mahiswaran, Uma Devi Krisnan, and Wong Chui Wen. 2016. Factors Effecting Towards Personal Bankruptcy among Residents: Case Study in Klang Valley, Malaysia. International Journal of Human Resource Studies 6: 98-109. [CrossRef] 
Sevim, Nurdan, Fatih Temizel, and Özlem Sayılır. 2012. The effects of financial literacy on the borrowing behavior of Turkish financial consumers. International Journal of Consumer Studies 35: 573-79. [CrossRef]

Stock, James H., and Mark W Watson. 2003. Forecasting output and inflation: The role of asset prices. Journal of Economic Literature 41: 788-829. [CrossRef]

Vitt, Lois A. 2004. Consumers' financial decisions and the psychology of values. Journal of Financial Service Professionals 58: 68-77.

Ward, Adrian F., and John G. Lynch Jr. 2019. On a need-to-know basis: How the distribution of responsibility between couples shapes financial literacy and financial outcomes. Journal of Consumer Research 45: 1013-36. [CrossRef]

Yusoff, Mohammed B., Fauziah Abu Hasan, and Suhaila Abdul Jalil. 2000. Globalisation, economic policy and equity: The case of Malaysia. In Poverty and Income Inequality in Developing Countries: A Policy Dialogue on the Effects of Globalisation. Paris: OECD Development Centre.

(C) 2020 by the authors. Licensee MDPI, Basel, Switzerland. This article is an open access article distributed under the terms and conditions of the Creative Commons Attribution (CC BY) license (http://creativecommons.org/licenses/by/4.0/). 